\title{
Female Entrepreneurship - An Appropriate Response to Gender Discrimination
}

\author{
Jacques Ascher*
}

\begin{abstract}
This study aims to discuss one of the most significant economic and social developments in the world - the rise of the female entrepreneurship phenomenon. Women entrepreneurship needs to be studied as a separate field for two main reasons: (a). Female entrepreneurship is an important source of economic growth in creating new jobs and by being genetically different: women provide different solutions to management and business issues; (b). Female entrepreneurship has been neglected, particularly in business research. Although equal opportunity for men and women in the entrepreneurial field is not a reality in the short range, the progress towards its achievement could be facilitated by better understanding of the impact of female entrepreneurship on society and its contribution to economic growth. This study addresses the growth in female entrepreneurship in the developed and developing countries, explores primary motivational and other factors that influence female entrepreneurship, reviews the main obstacles facing the female entrepreneur, and finally makes recommendations to policy-makers to encourage and support such activity. Keywords: entrepreneurship, female entrepreneurship.
\end{abstract}

\section{Introduction}

The author of this study dares to define, in an integrative manner, entrepreneurial activity as a calculated risk-taking and continuing process of innovational activities that embodies discovery, evaluation and exploitation of opportunities, judgment of the possibilities and making decisions in an identified uncertainty within a rapidly changing environment by using the spillover of knowledge and creating value out of this knowledge.

Entrepreneurship is a multilevel and complex phenomenon that gained importance in the global economy as a result of changes in employee qualifications, work contents, and psychological contracts in the employment field. Entrepreneurship contributes to economic growth in being a conveyor of new or existing knowledge spillover and creative ideas that might otherwise not be utilized and realized for the

* University of Pécs, Israel, jacques_ascher@mod.gov.il. 
benefit of all (Dejardin, 2002; Audretsch, Keilbach and Lehmann, 2006); Heertje, 2006; Langowitz and Minniti ,2007).Wennekers and Thurik,( 1999) note three levels of analysis when discussing the relationship between entrepreneurship and economic growth: the level of the individual entrepreneurs operating on their own or in teams and partnerships; the firm level; and the aggregate levels of industries, regions and national economies. They state that entrepreneurship has to do with the activities of individual persons, while the concept of economic growth is relevant at levels of firms, industries and nations. Thus, linking entrepreneurship to economic growth means linking the individual level to the aggregate levels. The most significant contribution of small businesses and entrepreneurial activity is their ability to innovate. By doing things more effectively and efficiently, firms enable economic growth, rise in wages, an improved work environment, and enable a higher standard of living. This result cannot occur without a new idea and its implementation (an economic experiment). If the idea is successful, it replaces something already existing.

This process, the creative destruction (Schumpeter, 1934, 1942), is essential for entrepreneurial activity. However, new ideas do not always lead to an advantage: an idea has to be kept alive and designed by a creative and innovative individual (Maddox, 1995).

Entrepreneurship plays an important role in exploring the knowledge and utilizing it to provide goods and services. Acs and Armington,( 2006) define entrepreneurship as "the process by which agents transform knowledge into wealth through new firm formation and growth, and then reconstitute wealth into opportunity for all through philanthropy" (p.155). The existing knowledge is apportioned among individuals, hence only a few know about an opportunity. Acs (2002) opines that this knowledge is obtained through an individual's own experience gained from his occupation and social life experiences.

During the past century, as a result of the changing society, accelerated entrepreneurial activity was accompanied by the significant participation of women in entrepreneurship across the globe. Ufuk and Ozgen, (2001) argue that entrepreneurial activity has been adopted by increasing numbers of women in recent years. Kelly, Brush, Greene, and Litovsky (2011), reinforce this statement by emphasizing that in recent years a significant number of women entered entrepreneurial activities and thus contributed significantly to entrepreneurship in all economies worldwide. They report that in 2010, 104 million women in 59 economies, representing over $52 \%$ of the world's population and $84 \%$ of the world's GDP, started and managed new enterprises. Another 83 million were running established businesses that they had started over $3 \frac{1}{2}$ years earlier. Taken together, 187 million women were involved in creating and operating enterprises, ranging from just over $1.5 \%$ to $45.4 \%$ of the adult female population in these 59 economies. These data emphasize the contribution women make to entrepreneurship globally. According to this report, female participation in entrepreneurship varies around the globe: $19.9 \%$ of women surveyed in factor-driven economies, stated that they were starting or running a new 
enterprise, $9.7 \%$ said so in efficiency-driven economies, and $3.9 \%$ in the innovationdriven economies.

Numerous studies focus on differences between female and male entrepreneurship.

Muktar (2002) points out that the differences between genders are in terms of management style, organizational structure of the enterprises, and the degree of empowerment in them.

Verhaul and Thurik,( 2001) use a panel of 2000 individuals, including 500 women, who started new firms in the Netherlands and found that women used low start-up capital, although there was no difference between the types of capital.

Cowling and Taylor,( 2001) find that the women entrepreneurs have better education than men, and that in the 1990s men entered entrepreneurship in considerably greater numbers than women.

In a study based on 4,200 entrepreneurs, including 405 women, Du Rietz and Henrekson, (2000) point out that the only area where women underperform, compared to men, is in growth in terms of sales.

A study conducted by the Center for Women's Business Research in 2009 measures the economic impact of the eight million women-owned businesses in the U.S. The estimated economic impact was $\$ 3$ trillion annually that translated into the creation and/or maintenance of more than 23 million jobs $-16 \%$ of all jobs in the U.S market. This report makes an interesting statement that illustrates the importance of female entrepreneurship in the world's strongest economy: "If U.S. women-owned businesses were their own country, they would have the 5th largest GDP in the world, trailing closely behind Germany, and ahead of countries including France, United Kingdom and Italy" (Center for Women's Business Research 2009).

Despite this trend, the "gender gap" in this activity remains wide. Women are still less likely to enter to such activity than men. Reynolds, Bygrave, Autio, Cox, and Hay (2002) indicate that female entrepreneurship varies significantly among 37 GEM 2002 (Global Entrepreneurship Monitor) countries, ranging from 0.6\% in Japan to the highest level of $18.5 \%$ in Thailand. Although in China, South Africa and Thailand the gap is narrower than in other countries, they conclude that there is no country where women are more active in entrepreneurship than men. Kelly, Brush, Greene, and Litovsky (2011), indicate that the proportion of women entrepreneurs varies significantly across countries, ranging from $16 \%$ in ROC to $55 \%$ in Ghana where there are six female entrepreneurs in Ghana for one male entrepreneur.

Minniti and Arenius,( 2003) state that participation in entrepreneurial activities does not vary between countries and genders with respect to age. For example, among both men and women the peak years of involvement in such activities are 25-34. Those over 55 have the lowest rate of participation, both among men and women. 


\section{The Impact of Female Entrepreneurship on the Economy}

The motivation for considering female entrepreneurship both in developing and developed countries derives from the increasing understanding of their important role in creating, running and developing businesses as a fundamental driver for economic growth (Acs, Bardasi, Estrin, and Svejnar 2011).

The rise of female entrepreneurship in industrialized economies is a recent phenomenon. Although the US is the most covered country regarding female entrepreneurship, women entrepreneurs in transition economies such as Hungary, Poland, Romania and Russia, in Latin America, South Asia and Southeast Asia, have a significant impact on the national economies.

In most developed economies, the real actors are no longer huge companies, but small and medium-sized firms that can provide solutions and respond to the needs arising from the new information technologies. Although in the past industrialization attracted more women into business, the present environments offer a new role for them to introduce innovation and creativity, especially where business connects with quality of life. Modernization challenges old regulations, barriers and old patterns of business that posed the major obstacles to female entrepreneurship. In the present era, which is characterized by vigorous domestic and global competition and an unstable economic environment, women entrepreneurs have a crucial role in creating new jobs, and hence reducing unemployment. Delmar and Holmquist, (2004) state that female entrepreneurs play an important role in the world economy and indicate that in the US 6.4 million selfemployed women provide jobs for 9.2 million people. This data is impressive when it is compared to the Fortune 500 largest firms that together employed 11.7 million people (Woodroof, 1996).

All over the globe, female entrepreneurship contributes to stability, to well-being among communities, and provides economic opportunities for disadvantaged groups including women, low wage earners, and minorities. Another contribution is the creation of wealth as well as employment.

Many women in developing countries remain illiterate and live in poor communities. This situation does not prevent them from participating in local economies and becoming entrepreneurs. Tiny enterprises enable them to improve their lives and those of many others by creating new jobs. The participation of women in economic life in developing countries contributes to a more human, cooperative, balanced and pleasant work environment in women-led enterprises, in which individual development is engraved.

Hisrish and Brush, (1988) argue that an increasing number of women are seeking to penetrate the world of entrepreneurship, although this activity entails many risks, and the expenditure of time and energy.

Numerous studies deal with the importance of female entrepreneurship in various regions in the world.

Kay, Gunterberg, Holz, and Wolter (2003), argue that in Germany more than one million women owned businesses that provide jobs for two million employees. Their turnover is 232 billion Euros. 
In the UK, women entrepreneurs have a growing share in the self-employed population and an important portion of the small enterprise population (Carter, Anderson, and Shaw, 2001).

The OECD 2003, in its Annual Labor Force Statistics, indicates the data of member economies regarding the distribution of gender in employment. According to this report, Turkey has the lowest share of women employment (13\%), while Portugal has the highest (40\%). The US and Canada are ranked highest, with a rate of $38-40 \%$. The Scandinavian countries have a share of $20-25 \%$.

Chun (1999) indicates that female employers in the APEC countries have, on average, $30 \%$ share in the employment market.

Saavedra (2001) provides statistics on self-employed women in Argentina, Brazil and Costa Rica which indicate that self-employment represents a real and important option for them, although Brazil leads over Argentina and Costa Rica. Nowadays, self-employment is increasing in Brazil and Costa Rica. The association of Caribbean States (ACS) 2012 report indicates that in Latin America women are more likely to be entrepreneurs than in other regions, and that the division there between men and women entrepreneurs is $24 \%$ versus $43 \%$ in Asia and $45 \%$ in Europe.

Based on this data, one can conclude that: (a). Female entrepreneurship has a strong effect on economies by increasing employment and sales and; (b). Women entrepreneurs play an important role in economic development and growth. The difficulty in estimating the real impact of the discussed phenomenon on the economy should be emphasized. Delmar and Holmquist, (2004) argue that there is a lack of knowledge about the actual impact of female entrepreneurship on the economy growth in most of OECD member countries.

\section{Factors Influencing Female Entrepreneurship}

No single factor motivates women to become an entrepreneur. Her reasons for that depend on several personal and external circumstances. Family support, social perceptions and attitudes towards women entrepreneurship are just some of the factors influencing the decision to become a female entrepreneur.

A survey that was conducted among 102 women in Israel (Tzemah 2000) points out the factors that effected them to become entrepreneurs. The results are illustrated in Table 1.

Table 1. Factors influencing women to enter to entrepreneurial activity

\begin{tabular}{lc}
\hline \multicolumn{1}{c}{ THE FACTOR } & PERCENTAGE \\
\hline Personal growth & $39 \%$ \\
Economic reasons & $30 \%$ \\
Desire for achievement & $15 \%$ \\
Recommendations from friends or family & $11 \%$ \\
High self-esteem & $9 \%$ \\
Creativity & $4 \%$ \\
Did not answer & $5 \%$ \\
\hline
\end{tabular}

Source: Tzemach (2000). 
Bruni, Gherardi, and Poggio (2004), draw up an interesting typology of female entrepreneurs' profiles based on driving factors and their incentives. The main points of the typology are presented in Table 2.

Table 2. Typology of profiles of female entrepreneurs

\begin{tabular}{ll}
\hline \multicolumn{1}{c}{ TYPE } & \multicolumn{1}{c}{ INCENTIVES } \\
\hline Aimless & $\begin{array}{l}\text { Young females who enter entrepreneurship as a result of } \\
\text { unemployment }\end{array}$ \\
\hline Success oriented & $\begin{array}{l}\text { Young women who perceive entrepreneurial activity as a long-term } \\
\text { strategy }\end{array}$ \\
\hline Strongly success oriented & $\begin{array}{l}\text { Women who perceive entrepreneurship as an opportunity for self- } \\
\text { fulfillment or as a means to overcome the "glass ceiling" phenomenon }\end{array}$ \\
\hline Dualists & Females seeking flexibility to balance their family and job obligations \\
\hline Return workers & $\begin{array}{l}\text { Women who left their jobs to care for family duties and are still } \\
\text { motivated to self-fulfillment outside their families }\end{array}$ \\
\hline Traditionalists & $\begin{array}{l}\text { Women who have a strong family entrepreneurial tradition } \\
\text { background }\end{array}$ \\
\hline Radicals & $\begin{array}{l}\text { Women who initiate introducing more pro-female tendencies in } \\
\text { society }\end{array}$ \\
\hline Source: Bruni, Grem
\end{tabular}

Source: Bruni, Gherardi, and Poggio (2004).

This chapter attempts to map the factors that may influence women to enter entrepreneurship. The author's conceptual model, illustrated in Figure 1, includes impacting factors on female entrepreneurship: motivation, demographic, social and economic environments, family network, education, and unemployment.

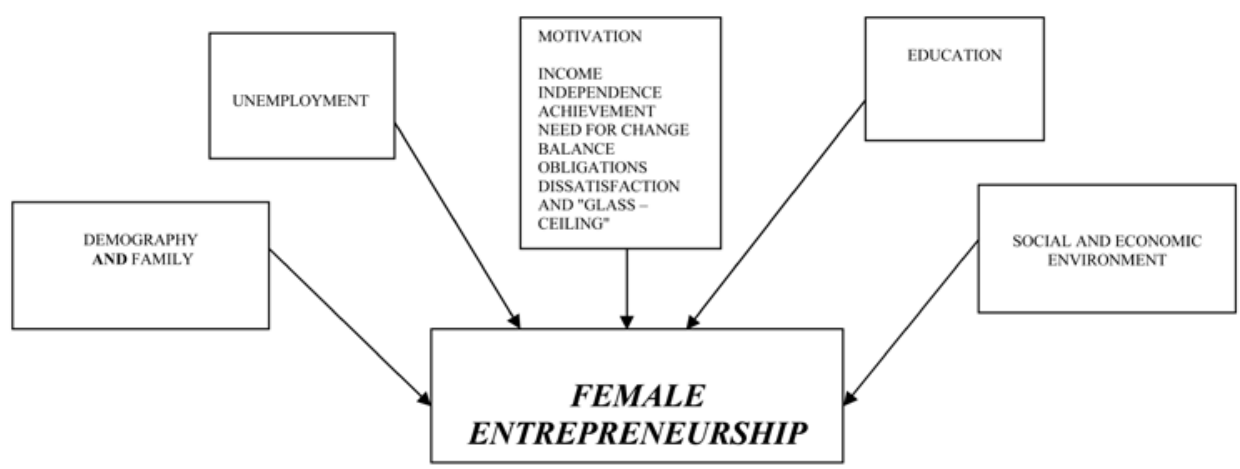

Figure 1. Conceptual model

\section{Motivational Factors}

The growth of the business depends partially on the entrepreneur's motivation. Although it is agreed that women differ from men in their personal and professional vision of life, there are some researchers who point out that female and male motivations regarding entrepreneurship initiatives are more similar than they are different (Buttner and Moore, 1997; Birley, 1989; Batory, 2004). Buttner and Moore, 
(1997) argue that both genders seek independence, autonomy and higher incomes for their efforts. Berry (1980) avers that the main different factor between genders is self-confidence. The author opines that in the present era, characterized by a strong feminist movement, Berry's argument has to be challenged. Buttner (1993) asserts that women entrepreneurs are more adaptive, have more social awareness and prefer longterm planning in comparison to men. Several studies have focused on distinguishing between the motivations of male and female entrepreneurs. While men are more likely to strive for monetary rewards (Manolova, Brush, and Edelman 2008), women have a tendency to balance social and economic goals (Holmquist and Sundin, 1988; Cadieux, Lorrain and Hugron, 2002). Some of the more recent studies also indicate that women tend to place greater emphasis on intrinsic goals (McGregor and Tweed, 2000; Cornet, Constantinidis, and Asendéi, 2003; Kirkwood, 2003; Manolova, et al. 2008). That is, women seek non-financial goals such as independence and work-family balance (Duchéneaut and Orhan, 2000; DeMartino and Barbato, 2003). In addition to the diversities indicated above, the author believes that it will be useful to clarify several motivational factors that support female initiatives to become entrepreneurs, although some of them are not specific to women.

1. Generate income - Coughlin and Thomas, (2002) argue that one of the most universal motivators for women to start businesses is the need to generate income. They opine that if they had equal opportunities as men to make money in jobs, the incentive behind this motivator would be much less. These researchers further conduct an interesting typology of economic motivations according to the level of the economy: (a). Economic motivation in developed countries; (b). Economic motivation in countries in transition, and; (c). Motivation in the developing world.

2. In the developed economies many women enter entrepreneurial activity to achieve those things that the system fails to provide. In countries in transition, the lack of economic options is the major factor for women becoming entrepreneurs. In Hungary, for example, women account for $41.1 \%$ of all entrepreneurs in businesses established after 1990 (Coughlin and Thomas, 2002). In the developing world, most women entrepreneurs are pushed to entrepreneurship as a result of poverty.

3. Pride in achievement - The need for achievement, personal growth and self determination are high motivating factors among women who have already started some entrepreneurial activities. Although success in business is measured in terms of profit, the need for achievement and the pride in it are paramount objectives among women.

4. Need for change - Women become entrepreneurs in order to make change. In contrast to men, they want to concentrate more on the client, to act more ethically and to contribute more to the community in addition to their economic aspirations. In cases wherein those goals are not achieved, women search for entrepreneurship. 
5. Autonomy and independence - Buttner and Moore, (1997) find that these factors are the most important factors in decisions amongst women to enter entrepreneurship. Their study focuses on a group of women in managerial level positions who left jobs in firms to start new self-owned enterprises. Reflecting on family responsibility expected from women, Simonin (2006) points out that many women enter entrepreneurship activities because of the autonomy and flexibility that are essential to the fulfillment of their family obligations. Social expectations from the female role and responsibilities in the family are still valid (Orhan and Scott, 2001).

6. Women having a motherhood role are less satisfied with their careers and perceive entrepreneurship as a tool to adjust their career needs to their family obligations. Noble (1986) argues that men perceive entrepreneurship as a business decision while women perceive it as an integrating and balancing tool between family and career needs.

7. Frustration and boredom with the present job - These factors highly impact on women to embark on entrepreneurship. A study by Cromie and Hayes, (1991) finds that those factors were perceived by women as the main reasons for entering entrepreneurship. The present era enables women to have an opportunity for an exciting and satisfying journey in their occupation.

8. Dissatisfaction with the present job - Many women are driven to improve and expand new ideas, products and services by self-owned businesses. They fully believe they can do better than they currently do in their present jobs.

9. Work environment - Some women perceive work environments in big firms as not friendly and hence they search for entrepreneurship to change this situation (Orhan and Scott, 2001).

10. "Glass ceiling" (Coughlin and Thomas, 2002) - This factor is a significant motivational factor deriving from the fact that there are many obstacles preventing from women from achieving managerial jobs. A significant number of women take a risky step towards entrepreneurship as a result of situations in which in their actual jobs they hit the "glass ceiling" or feel frustrated and unchallenged.

Orhan and Scott,( 2001) argue that entrepreneurship motivators can be best explained by push and pull factors, and that entrepreneurship is not a clear choice between the two factors, but a combination of them. Walker and Webster,( 2007) argue that women are "pushed" rather than "pulled" into business and that recent studies indicate that many women choose self-employment. According to Simonin (2006) the main components of the pulling factors are independence, selfaccomplishment, a passion for initiative, willingness to generate income, social status, and power. He mapped the components of the pushing factors as low family income, lack of satisfaction with salary, difficulties in finding a job, and the necessity to find a flexible job that enables balancing both job and family obligations. 
Cohoon, Wadhwa and Michell (2010), collected in their study data from 549 respondents during 2008-2009 to explore male and female entrepreneurs' motivators. The individuals included in the research sample were successful entrepreneurs, $59 \%$ of whom had founded more than one enterprise. Their findings were:

- More than $56 \%$ of women, but only $31 \%$ of men were motivated to become entrepreneurs by a company founder's recruitment efforts.

- A family member or an entrepreneurial friend served as a role model for more than a half of the women and many of the men.

- $5 \%$ of both genders cited the reason that they were out at work as a motivator to enter to entrepreneurial activity.

- A slightly higher percentage of women than men were motivated by their dissatisfaction from working for someone else.

- Prior experience was significantly important to women who perceive it as crucial to success.

- Women emphasized more than men their professional and social networks as very important factors to the success of their recent startups.

- Surprisingly, and in contradiction to the belief that women entrepreneurs have less access to capital than men (Robb and Coleman, 2009), no differences were found in the types of funding between the two genders with one exception: women, much more than men, secured their main funding from business partners. No significant gender differences were found in the use of bank loans and venture capital.

\section{Demographic Environment and Family Structure}

Population growth has an impact on entrepreneurship among men and women in low income countries. In these countries, growth in population increases demand and generates competition for few jobs among more people and thus encourages more women to enter entrepreneurship activities.

For women, entrepreneurship can be a way to overcome institutional and cultural barriers as well as a tool to provide the family with additional income. It is interesting that female entrepreneurship is more frequent in low income countries with high birth rates. This is a very surprising situation since the perception is that high birth rates should create lesser ability among women to become entrepreneurs. In fact, the parenting responsibilities of women are the main reason for their high participation in entrepreneurial activities. Women, especially in countries with low income rates, have an incentive to build their owned work environment according to their moral, economic obligations and responsibilities towards their children.

Norms relating to marriage also influence female entrepreneurship (Chameleon and Wright, 1997). In the present era, more people, particularly women in developed countries, are living alone. This situation forces them to participate in entrepreneurial activities. 


\section{Education}

In modern economies, the education level of the population has an impact on economic growth. Worldwide, educated women have better access to the existing opportunities, to more attractive jobs with high salaries. Reynolds et al. (2002), indicate a strong relationship between education and entrepreneurial success.

Rather surprisingly, entrepreneurial activity is higher in countries where most of the female population suffers from illiteracy. This can be explained by the situation in which educated women entrepreneurs employ illiterate women in small business not requiring special skills and abilities

\section{Social and Economic Environments}

Generally, good economic conditions are a supportive and encouraging factor for female entrepreneurship. In economies with high income rates, the correlation between unofficial economic activities and entrepreneurship is negative whilst in low income economies it is positive (Minniti and Arenius, 2003).

An additional significant factor that determines the volume of female entrepreneurship is the capability of financing this type of activity. Verhaul and Thurik,( 2001) argue that women entrepreneurs have a small starting capital and that they need higher bank loans. Small capital may be a discouraging factor for women who initiate entrepreneurship activity. Higher bank loans may be related to the fact that women are more careful and prudent in taking risks and in acting in an uncertain environment. Relying on external financing has a more significant impact on developed economies as in these economies women are entering entrepreneurship activities especially in more sophisticated fields. Normally, an investor expects a short timetable for ROI as a business strategy; such a strategy may not suit women with a more conservative approach to business.

\section{Unemployment}

Reynolds et al. (2002), argue that there is a negative correlation between female entrepreneurship and unemployment especially in economies characterized by low income rates. This means that there is a decrease in female entrepreneurship in cases of unemployment, due to a reduction in demands that is conveyed to situations wherein expected profits are low. In these cases women are discouraged from embarking on new business activities.

\section{Obstacles to Female Entrepreneurship}

The previous chapter dealt with the factors influencing female entrepreneurship. As discussed there are many motivational and environmental influencing factors that may be altered over time by different events and impact on obstacles during the process. Therefore, it is not sufficient to focus on them, but it is also essential to review the main obstacles facing the female entrepreneur along the whole process of entrepreneurship. These obstacles are universal and similarly confronted by female entrepreneurs in different parts of the world (Gupta, Turban, Wasti, and Sikdar, 2005). 
Delmar and Holmquist, (2004) note a four-stage entrepreneurial process: (a). Identification of an opportunity and willingness to enter the process; (b). Achievement of essential information, resources and start up; (c). Management of the business and; (d). Growth of the business. This chapter aims to review the main obstacles in each stage.

\section{Obstacles in the Stage of Identification of an Opportunity and Willingness to Embark on the Entrepreneurial Activity}

\section{Absence of benchmarking possibilities}

Shapiro and Skolt,( 1982) relate the benchmarking possibilities to the existence of role models. They relate the absence of women role models to their poor presence as entrepreneurs in the past. The author defines role models as female entrepreneurs who serve as sources of imitation in their attitudes, decisions and actions, for those women who just began their journey and mentor them. The absence of role models is seen as a barrier by $64 \%$ of women in the US (Catalyst - Conference Board , 2002).

\section{Lack of experience}

Ability, knowledge and skills to explore and exploit opportunities depend on work experience and education. Delmar and Holmquist (2004), argue that women lack the experience to explore the opportunities although educated and skilled women have more chances to do so more than uneducated women.

\section{Lack of social capital}

Women are less involved in social networking and have a different network from men. In this context, one must emphasize that one of the most important factors explaining startups is the entrepreneur's social network structure. The networks in which women are engaged are mostly suitable to their family duties. This situation may become an obstacle to their business life. Women face "the double burden" syndrome, which is currently inherent in our model of society, in efforts to balance work and domestic responsibilities. The modern business world is urging "anytime and anywhere" performance requiring unfailing availability and total geographical mobility at all times (Women Matter, 2010). The human capital and social relations of women are different from men due to their networks. A female entrepreneur has not many possibilities to achieve essential resources, support and take advantage of knowledge needed to start a new enterprise.

\section{Lack of financial capital}

Financial capital is a crucial and vital asset for the entire entrepreneurial process. Lack of financial capital is frequent in the developing countries where women are not independent regarding their incomes and are mostly controlled by their husbands. The literature supports the fact that female entrepreneurs, mostly in developing countries, 
face obstacles in obtaining credit for their entrepreneurial activities (Kuzilwa, 2005; Iganiga, 2008; Ibru, 2009; Okupkpara, 2009). The 2004 OECD report, presented at the 2nd OECD conference held in Istanbul, found the access to finance to be one of the specific obstacles to female entrepreneurship. In some African countries the obstacles facing a female to save and invest money are even both legal ad cultural. Moreover, research conducted in developed economies indicates that barriers still exist to women entrepreneurs obtaining external finance, although such obstacles are diminishing as financial institutions are becoming more sensitive to gender issues and start to perceive female entrepreneurs as a potential source of profit for them (Kay, Gunterberg, Holz, and Wolter, 2003).

\section{Lack of time}

Another obstacle is lack of time as a direct result of family responsibilities. Women have less time than men to develop skills and obtain updated knowledge. Lack of time prevents them from taking essential steps to achieve financial support from banks, to participate in training programs to acquire necessary skills and knowledge, and to seek out better customers or suppliers. This lack of free time has been observed in a number of studies especially regarding various developing countries such as Bangladesh (Karim, 2000), and Côte d'Ivoire, Ethiopia, Mali, Morocco, Senegal and Zimbabwe (de Groot, 2001).The results suggest that lack of time is a barrier for most women, in most economies.

\section{Risk perception}

The author believes that in most cases women are more concerned about the consequences of embarking on entrepreneurship because they fear that such activity will place greater demands on them in terms of time. Modifications in the political, economic and social environment, embodied in appropriate legislation, may contribute to changes in attitudes towards risk-taking among female entrepreneurs. According to the research findings, females tend to have lower risk propensity than male entrepreneurs, which completely mediates the effect of gender on risk behavior (Ivanova Yordanova and Ivanova Alexandrova-Boshnakova, 2011).

\section{Obstacles in the Start-Up Phase}

\section{Gender discrimination in external financing}

Generally, it is difficult to state that women have more difficulties than men in obtaining capital. However, women have lower financial assets than men and hence they depend more on external finance. Banks and other financial institutions try to optimize the loans based on clients who are able to start a new business, survive and grow. It is difficult to claim that discrimination is based on gender but it is rather logical that women lacking knowledge and skills have more difficulties in achieving external financing. Furthermore, women are not perceived as entrepreneurs because 
of prejudice, social networks and family obligations. This perception prevents women from attaining external financial capital. Stereotypical perceptions are well reflected in Buttner's 1993 study, in which bank loan officers were asked to rate men and women according to nine dimensions relating to successful entrepreneurship. The findings were interesting; women were rated lower than men on seven dimensions out of nine.

In developing countries, women confront problems in obtaining financial capital due to their inferior social position. Although some obstacles still exist in developed economies, they are diminishing since the financial institutions are becoming increasingly aware of the abilities of women to enter entrepreneurial activities. Coleman and Carsky, (1996) argue that female entrepreneurs use less bank loans than men and they tend to finance their business activities by personal savings, profit, credit cards and family assistance. Haynes and Helms,(2000) find that, in addition to bank loans, female entrepreneurs surveyed in their research noted other resources in the start-up phase: personal savings, credit cards, friends, venture capital, and the sale of property.

Ufuk and Ozgen,(2001) observe that, among 220 women entrepreneurs who participated in their research, $82.3 \%$ stated that they confronted some problems in the start-up phase and 203 of them identified financing as the most significant.

\section{Obstacles in the Management Phase}

\section{Stereotypical attitudes}

The common perception is that women confront stereotypical attitudes on a daily basis in their contacts with banks, clients and suppliers in the management phase of their business. Nevertheless, Lee - Gosselin and Grise,(1990) find that attitudes regarding female entrepreneurs were positive (52\%) and negative (15\%).

\section{Obstacles in the Growing Phase}

\section{Family and financing issues}

Balancing family and work responsibilities concerning greater penetration into the market and attracting more customers is a very hard mission to accomplish in the growing phase of the business. Women who have more domestic responsibilities have less time to develop and leverage their business. According to European Commission Statistics 2006, on average European women devote twice as much time as men to domestic tasks. Women spend four hours and 29 minutes a day, compared with two hours and 18 minutes for men (Women Matter, 2010).

\section{Recommendations to Policy Makers}

Public policies should be aimed at supporting economic development by encouraging innovation, creativity, and growth. Governments should support the formation, development and growth of small and medium-size enterprises and encourage 
individuals to enter entrepreneurial activities. Policy-makers should perceive female entrepreneurs as a special group that deserves special attention and approach.

The author of this manuscript perceives the establishment of an institutional and egulatory environment that facilitates the entrance of women to entrepreneurship, as a crucial step in reducing the obstacles and administrative barriers.

The following recommendations should be useful to policy-makers in supporting female entrepreneurs during the entire life cycle of their business:

1. Remove maximum legal and regulatory barriers to female entrepreneurship and support pro-family public policies.

2. Foster an economic regulatory environment including taxation to strengthen female entrepreneurship.

3. Increase small and medium-sized preparation programs at all levels of the education system.

4. Provide support, mentoring, coaching and training not only at the start-up phase.

5. Understand the way women perceive risk before designing support.

6. Promote equal opportunity and abolish gender discrimination.

7. Address female concerns regarding business growth and expansion in designing government supporting programs.

8. Strengthen policy coordination regarding government activities to promote female entrepreneurship.

9. Formulate strategies to provide more access to information on international markets and facilities that information and communication technology (ICT) provides.

10. Incorporate female entrepreneurship dimensions in SME related policies at the design phase.

11. Promote appropriate networks to provide knowledge and tools necessary for the development and extension of female entrepreneurship; coordinate domestic and global networks.

12. Follow up and evaluate systematically and continuously the effect of related policies on women entrepreneurship and the extent to which women take advantage of them.

\section{Conclusion}

There is no doubt that female entrepreneurship is one of the outstanding phenomena in modern economy. A growing number of women participating in entrepreneurial activities, reflects the transformation in economic and social fields. Women are increasingly crossing the economic and social barriers. They have greater confidence in their skills and abilities to build their enterprises equally, if not more successfully, than men.

Individual motivation, family structure, education, demography, unemployment, and social and economic environments are the main factors influencing female 
entrepreneurship. These factors are the main determinants of the differences between women and men regarding risk perceptions in the entrepreneurial process.

Women entrepreneurs face several obstacles along the life cycle of their businesses: the absence of benchmarking possibilities, the lack of financial and social capital, of experience, time, gender discrimination, stereotype attitudes, and, finally, domestic issues.

Many policy-makers perceive female entrepreneurship as a phenomenon that contributes to economic growth. This perception should be accompanied by special attention, support and treatment. Actually, there is much more to accomplish to encourage and assist women who aspire to embark on entrepreneurial activity.

\section{References}

Acs, Z.J. (2002). Innovations and growth of the cities. Cheltnam: Edward Elgar.

Acs, Z.J., and Armington, C.B. (2006). Entrepreneurship, geography and American growth. N.Y.: Cambridge University Press.

Acs, Z.J., Bardasi, E., Estrin, S., and Svejnar, J. (2011). Introduction to special issue of Small Business Economics on female entrepreneurship in developed and developing economies. Small Business Economics, 37 (4) 393-396.

ACS, (2012). Report on women's entrepreneurial participation in the Greater Caribbean Countries.

Audretsch, D. B., Keilbach, M.C., and Lehmann, E.E. (2006). Entrepreneurship and economic growth. Oxford: Oxford University Press.

Batory, S. (2004). A gender analysis of potential entrepreneurs: Their motivation to be self-employed and actual self concepts. Wilkes University.

Berry, M.C. (1980). Targeting more aid to women entrepreneurs. Venture, 294-304.

Birley, S. (1989). Female entrepreneurs: Are they really different? Journal of Small Business Management, 27 (1) $32-37$.

Burges, C., Filion, L.J., and Simard, G. (2008). Specifics of the venture creation process by women. Proceedings of the Annual Conference of the ICSB/CIPE, Halifax.

Buttner, E. H. (1993). Female entrepreneurs: How far have they come? Business Horizons, 36 (2) 59-65.

Buttner, E.H., and Moore, D.P. (1997). Women's organizational exodus to entrepreneurship: Self-reported motivations and correlations with success. Journal of Business Management, 34-46.

Bruni, A., Gherardi, S., and Poggio, B. (2004). Entrepreneur - reality, gender and the study of women entrepreneurs. Journal of Organizational Change Management, 17 (3) 256-268.

Cadieux, L., Lorrain, J., and Hugron, P. (2002). La succession dans les entreprises familiales dirigées par les femmes: un problématque en quete de chercheurs. Revue international P.M.E. 15(1) 115-130.

Carter, S.L., Anderson, S., and Shaw, E. (2001). Women's business ownership: A review of the academic, popular and internet literature. (Report). London, UK: Small Business Service. 
Catalyst - Conference Board (2002). Women in leadership: A European business imperative.

Center for Women's Business Research (2009). The economic impact of women-owned business in the United States.

Chun, B.J. (1999). Women entrepreneurs in SMEs in the APEC region. Singapore: APEC.

Cohoon, J., Wadhwa, V., and Michell, L. (2009). Are successful women entrepreneurs different from men? Kaufmann Foundation.

Coleman, S., and Carsley, M. (1996). Understanding the market of women-owned businesses. Journal of Banking, 18 (2), $47-49$.

Cornet, A., Constantinidis, C., and Asendéi, S. (2003). Les femmes entrepreneurs face â la formation, aux financement et aux réseaux. Belgique: Rapport national.

Coughlin, J.H., and Thomas, R.E. (2002). The rise of women entrepreneurs: People, process, and global trends. Westport: Quarum Books.

Cowling, M., and Taylor, M. (2001). Entrepreneurial women and men: Two different species? Small Business Economics, 16 (3) 167-175.

Cromie, S., and Hayes, J. (1991). Business ownership as a means of overcoming job dissatisfaction. Personnel Review, 22, (1) 19-25.

De Groot, T.U. (2001). Women entrepreneurship development in selected African countries. Vienna: UNIDO.

Dejardin, M. (2000). Entrepreneurship and economic growth: An obvious conjunction? Institute for Development Strategies.

Delmar, F., and Holmquist, C. (2004). Women entrepreneurship: Issues and policies. $O E C D$.

DeMartino, R., and Barbato, R. (2003). Differences between women and men MBA entrepreneurs: Exploring family flexibility and wealth creation as career motivators. Journal of Business Venturing, 18 (2003) 815-832.

Duchéneaut, B., and Orhan, M. (2000). Les femmes entrepreneurs en France: Percée de femmes dans un monde construit au masculine. Paris: Seli Arslan.

Du Rietz, A., and Henkerson, H. (2000). Testing the female underperformance hypothesis. Small Business Economics, 14 (1) 1-10.

European Commission Statistics (2006). Executive Boards.

Gupta, V.K., Turban, D., Wasti, S.A., and Sikdar, A. (2005). Entrepreneurship and stereotypes: Are entrepreneurs from Mars and from Venus? Academy of Management Proceedings, PC1 - C6.

Haynes, P,J., and Helms, M.M., (2000). A profile of the growing entrepreneur segment. Bank Marketing, 32 (5) 28-35.

Heertje, A. (2006). Schumpeter on the economics of innovation and the development of capitalism. Northampton, MA: Edwin Elgar.

Holmquist, C., and Sundin, E. (1988). Women as entrepreneurs in Sweden: Conclusions from a survey. Wellesley, MA: Frontiers of Entrepreneurship Research, 643-653.

Ibru, C. (2009). Growing microfinance through new technologies. Nigeria: Federal University of Technology. 
Iganiga, B.O. (2008). Much ado about nothing: The case of Nigerian microfinance policy measures, institutions and operations. Journal of Social Sciences, 7 (2) 89-101.

Ivanova Yordanova, D., and Alexandrova-Boshnakova, M. (2001). Gender effects on risk - taking of entrepreneurs: evidence from Bulgaria. International Journal of Entrepreneurial Behavior and Research, 17 (3) 272-295.

Karim, N. A. (2000). Jobs, gender and small enterprises in Bangladesh: Factors affecting women entrepreneurs in small and cottage industries in Bangladesh. Geneva: ILO. .

Kay, R., Gunterberg, B., Holz, V., and Wolter, H.J. (2003). Female entrepreneurs in Germany. Bonn: Institut für Mittelstandsforshung.

Kelly, D.J., Brush, C.G., Greene, P.G., and Litovsky, Y. (2011). Women entrepreneurship worldwide. (Executive Report). Global Entrepreneurship Monitor (GEM).

Kirkwood, J. (2003). The motivation of entrepreneurs: Comparing women and men. Proceedings of the 48th World Conference of the ICSB, Belfast.

Kuzilwa, J. (2005). The role of credit small business success: A study of national entrepreneurship development fund in Tanzania. The Journal of Entrepreneurship, 4 (2) 131-161.

Langowitz, N., and Minniti, M. (2007). The entrepreneurial propensity of women. Entrepreneurship Theory and Practice, 31(3) 341-360.

Lee - Gosselin ,H.L., and Grise, J. (1990), Are women owner - managers challenging our definitions of entrepreneurship? - An in - dept survey. Journal of Business Ethics, 6 , $423-433$.

Maddox, R. (1995). Inc. your dreams. USA: Penguin Books.

Manolova, T.S., Brush, G.B., and Edelman, L.F. (2008). What do woman entrepreneurs want? Strategic Change, 17, 69-82.

McGregor, J., and Tweed, D. (2000). Women managers and business owners in New Zealand. In M.J. Davidson, and R.J. Burke, (Eds.), Women management: Current research issues, 40-52. Ca: Sage.

Minniti, M., and Arenius, P. (2003). Women entrepreneurship. First Annual Entrepreneurship Symposium, U.N. Head Quarters.

Noble, B. (1986). A sense of self. Venture, July, 34-36.

OECD, (2003). Annual labor force statistics. Paris: OECD.

OECD, (2004). Report on women entrepreneurship issues and policies. Istanbul: OECD.

Orhan, M., and Scott, D. (2001). Why women enter into entrepreneurship: An explanatory model. Women Management Review, 16 (5/6) 232 - 243.

Okpukpara, B. (2009). Microfinance paper wrap-up: Strategies for effective loan delivery to small scale enterprises in rural Nigeria. Journal of Development and Agricultural Economics, 1 (2) 41-48.

Reynolds, P.D., Bygrave, W. D., Autio, E., Cox, L. W., and Hay, M (2002). Global entrepreneurship monitor (Executive Report).

Robb, A., and Coleman, S. (2009). Characteristics of new firms: A comparison by gender. Kaufmann Foundation. 
Saavedra, L.A. (2001). Female wage inequality in Latin American labor markets. Washington, DC: The World Bank.

Schumpeter, J.A. (1934). The theory of economic development. Cambridge: Harvard University Press.

Schumpeter, J.A. (1942). Capitalism, socialism and democracy. NY: Harper and Row.

Simonin, M. (2006). Women entrepreneurship. Business Strategy and International Business, Helsinki University of Technology, 91-167.

Tzemah, M. (2000). A survey on women characteristics in business. Israel: SMEs Authority (In Hebrew).

Ufuk, H., and Ozgen, O. (2001). The profile of women entrepreneurs: A sample from Turkey. International Journal of Consumer Studies, 25 (4) 299-308.

Verhaul, L., and Thurik, R. (2001). Start-up capital: Does gender matter? Small Business Economics, 16 (4) 329-345.

Walker, E.A., and Webster, B.J. (2007). Gender, age and self-employment: Some things to change, some stay the same. Women Management Review, 22(2) 122-135.

Wennekers, S., and Thurik, R. (1999). Linking entrepreneurship to economic growth. Small Business Economics, 13 (1) 27-55.

Women Matter (2010).

\begin{abstract}
Polish)
Niniejsza praca zajmuje się jednym z najważniejszych zjawisk ekonomicznych i społecznych na świecie - zjawiskiem wzrostu przedsiębiorczości kobiet. Przedsiębiorczość kobiet należy analizować jako oddzielnq dyscyplinę wiedzy z dwóch głównych powodów:

(a). Przedsiębiorczość kobiet jest ważnym źródłem wzrostu gospodarczego w zakresie tworzenia nowych miejsc pracy oraz, z powodu odmienności genetycznej, kobiety znajdujq inne rozwiqzania problemów biznesowych i tych zwiqzanych z zarzqdzaniem;

(b). Przedsiębiorczość kobiet jest tematem zaniedbywanym $w$ badaniach biznesowych. Chociaż nieprędko zrównamy szanse mężczyzn i kobiet na polu przedsiębiorczości, postęp $w$ tej dziedzinie można przyspieszyć lepiej rozumiejqc wpływ przedsiębiorczości kobiet na społeczeństwo i jego wkład we wzrost gospodarczy. Niniejsza praca zajmuje się rosnqqca przedsiębiorczościq kobiet zarówno w krajach rozwiniętych jak i rozwijających się, bada podstawowe czynniki motywacyjne i inne wpływajqce na przedsiębiorczość kobiet, omawia główne przeszkody z jakimi muszq zmierzyć się przedsiębiorcze kobiety i wreszcie proponuje pewne rekomendacje dla decydentów majq̨ce na celu zachęcanie i wspieranie tej aktywności. Słowa kluczowe: przedsiębiorczość, przedsiębiorczość kobiet.
\end{abstract}

